\title{
INVESTIGACIÓN
}

\section{Quality of virgin olive oil as influenced by origin area}

\author{
By A. Ranalli ${ }^{1}$, G. De Mattia ${ }^{1}$, M. Patumi ${ }^{2}$ and P. Proietti ${ }^{3}$ \\ 1 Istituto Sperimentale per l'Elaiotecnica, Contrada Fonte Umano 37, \\ 65013 Città S. Angelo, Pescara, Italy. \\ 2 Istituto di Ricerche sulla Olivicoltura-CNR, Via Madonna Alta 128, 06128 Perugia, Italy. \\ 3 Istituto di Coltivazioni Arboree-Università degli Studi, Via XX Borgo XX Giugno 76, \\ 06100 Perugia, Italy
}

\section{RESUMEN}

\section{Calidad del aceite de oliva virgen con relación a la} zona de origen.

Se ha realizado una investigación para evidenciar la importancia y la influencia que la zona de origen tiene sobre las variables analíticas del aceite de oliva virgen. Han sido seleccionadas cinco zonas geográficas de Italia: (i) una cerca de la Facultad de Agraria de la Universidad de Perusa (UNI-PG); (ii) una cerca del Instituto para la Olivicultura Consejo Nacional de las Investigaciones de Perusa (CNI-PG); (iii) una zona próxima al Instituto Experimental para la Olivicultura de Espoleto (IEO-ESP); (iv) una zona cerca Instituto Técnico Agrario de Pescia (ITA-PES); (v) una zona cerca de la Facultad de Agraria de la Universidad de Florencia (UNI-FL).

De estas zonas han sido tomadas muestras de aceitunas de las variedades Frantoio, Leccino y Moraiolo, las cuales han sido procesadas con un micro-molino de aceite. Los resultados de la investigación, han puesto en evidencia que los parámetros de la calidad, tipismo y vida útil, y el flavor de los aceites estaban bastante influenciados por la zona de origen, es decir por los factores climáticos y pedológicos del medio agrícola. Se debe subrayar la influencia observada en algunos grupos de componentes, como fenoles, tocoferoles, compuestos volátiles aromáticos y ácidos grasos, puesto que estas substancias están estrechamente relacionadas con la calidad y el tipismo del producto. Algunos parámetros de la pureza están también influenciados por las variables ambientales.

PALABRAS-CLAVE: Aceite de oliva - Calidad - Duración Flavor - Tipismo - Zona de origen.

\section{SUMMARY}

\section{Quality of virgin olive oil as influenced by origin area.}

To elucidate the weight and the influence of the origin area on the analytical and compositional variables of olive oil, an investigation was carried out. Five Italian geographical zones were chosen. They were in the neighbour of the: (i) Faculty of Agriculture of University of Perugia (UNI-PG); (ii) the Olive Growing Institute-National Research Council of Perugia (NRC-PG); (iii) the Experimental Olive Growing Institute of Spoleto (EOI-SPOL); (iv) the Agricultural Technical Institute of Pescia (ATI-PES); and (v) the Faculty of Agriculture of University of Florence (UNI-FL). From these areas, Frantoio, Leccino and Moraiolo olive variety samples were taken, which were processed by a mini oil-mill. The research results showed that the quality, typicality and shelf-life parameters and the flavour of the oils were largely influenced by the origin zone, i.e., by the climatic and pedologic factors of the production environment. The influence exerted on some oil constituent groups, as phenols, tocopherols, aromatic volatile compounds, and fatty acids, should be emphasized as these components are closely related to the quality and typicality of product. Some oil genuineness parameters were affected as well by the environmental variables.

KEY-WORDS: Flavour - Olive oil - Origin area - Quality - Shelflife - Typicality.

\section{INTRODUCTION}

Climatic and pedologic factors, cultivation and agronomic techniques, harvesting, carriage and storage systems of olives, ripening degree of drupes, genetic factors (cultivar), and processing techniques, affect the analytical characteristics of oil (Solinas and Angerosa, 1989; Olias, 1992; Bianchi and Pozzi, 1994). They also are influenced by the kind of container used to store the product (Ranalli, 1989).

The composition of oil is in large measure attributed to the agronomic or geographical origin (Servili et al., 1990; Osman et al., 1994). In fact, certain zones are renowned for the characteristics of their oils. In order to certify the origin zone of typical oils with excellent characteristics, Italy issued the law 169/92 (on the COD, controlled origin denomination) and European Economic Community (EEC) issued the Regulations 2081/92 (on the POD, protect origin denomination, and $\mathrm{PGI}$, protect geographical indication) and 2082/92 (on the specificity attestations). These acronyms represent certification marks which are reported on the labels of containers. In this way virgin oil is valorised and its quality protected.

Concerning the geographical characterisation of virgin olive oil origin, and the composition variability due to the cultivation environment, many works have 
been published (Forina and Tiscornia, 1982; Forina et al., 1983; Derde et al., 1984; Montedoro and Garofalo, 1984; Aparicio et al., 1987; Kiritsakis and Markakis, 1987; Leardi and Paganuzzi, 1987; Aparicio, 1988; Forcadell et al., 1988; Pannelli and Montedoro, 1988; Armanino et al., 1989; Aparicio et al., 1993; Cimato et al., 1990; Servili et al., 1990; Solinas et al., 1990; Aparicio et al., 1991; Fiorino and Nizzi Griffi, 1991; Ferreiro and Aparicio, 1992; Lotti et al., 1992; Montedoro, 1992; Montedoro and Servili, 1992; Solinas et al., 1992; Alonso and Aparicio, 1993; Deidda et al., 1993; Garcia and Aparicio, 1993; Giglioli et al., 1993; Montedoro et al., 1993; Montedoro et al., 1993; Montedoro et al., 1993; Montedoro et al., 1993; Pannelli et al., 1993; Pannelli et al., 1993; Servili et al., 1993; Tous and Romero, 1993; Tsimidou and Karakostas, 1993; Aparicio and Alonso, 1994; Aparicio et al., 1994; Aparicio et al., 1994; Drava et al., 1994; Leone et al., 1994; Osman et al., 1994; Balestrieri et al., 1995; Montedoro et al., 1995; Pannelli and Servili, 1995; Angerosa et al., 1996; Bianchi et al., 1996).

The relationships between analytical oil variables and pedologic and climatic variables have been less studied (Ferreiro and Aparicio, 1992; Pannelli et al., 1993). According to Ferreiro and Aparicio (1992) some sterols, triterpenic alcohols and hydrocarbons are correlated negatively with altitude. The influence of elevation variable on the composition of virgin oils was earlier pointed out by Armanino et al. (1989) and later by Osman et al., (1994); the latter authors observed that the oils from $100 \mathrm{~m}$ altitude were higher in phenols and unsaturated fatty acids, as well as had a higher oxidative stability and free acidity compared to $400 \mathrm{~m}$ elevation. The unsaturated fatty acid variable appeared also correlated with low temperatures of the cultivation location (Kiritsakis and Markakis, 1987). The positive influence of low temperatures on the oleic acid and unsaturated fatty acids/saturated fatty acids ratio values was also noted by Lotti et al., (1982) and Fiorino and Nizzi Griffi (1991). Pannelli et al., (1993) showed that rainfall was correlated negatively with the total oil phenol content and positively with total volatiles. Servili et al., (1990) found that the skeleton percentage of soil was correlated positively with phenol content of oils (possibly because it influences negatively the moisture percentage of soil). Other correlations were checked by Angerosa et al., (1996).

Notwithstanding some of the authors, using multivariate statistics, were even able to differentiate the oils produced under different levels of some agronomic variables, the scientific explanation of the aforementioned relationships has not given yet.

The effects of the environment/cultivar combination are very complex and play a basic role in determining the olive oil quality. The other factors can only modify the primary effects. These, and noticeably the relationships between the two above kinds of variables, have not yet been elucidated well and further studies are needed.

We are accomplishing a pluriannual investigation, whose first results, obtained in 1996, are given in this paper. On the other hand, several Italian virgin olive oils some of which are produced in well-known zones, have not yet been characterised well. Thus, it is not easy to get them a certification mark by the competent institution. This paper pretends to contribute to the solution of the problem.

The most important olive varieties cultivated in Italy for the production of COD oils are Coratina (Apulia), Biancolilla (Sicily), Rotondello (Campania), Bosana (Sardinia), Caroleo (Calabria), Ogliarola (Basilicata), Gentile Larino (Molise), Dritta (Abruzzo), Raja and Canino (Lazio), Sargano (Marche), Moraiolo (Umbria), Leccino and Frantoio (Tuscany), Taggiasca (Liguria).

The Italian regional agricultural environments are usually characterised by many micro-climates and this could notably modify the analytical features of the oils from the above olive varieties.

\section{EXPERIMENTAL}

\subsection{Geographical location and olive growing features of the selected areas.}

Three areas located in Umbria and two located in Tuscany, two central Italian regions where virgin olive oils of good quality are produced due to both good environmental characteristics and good processing technologies, were chosen.

The olive varieties considered in this study are cultivated in both the regions and this is the reason that led us to select them. Most of the Italian regions have autochthonous varieties. Frantoio, Leccino, Pendolino and Maurino olive varieties are the most cultivated in Tuscany, while Moraiolo and Dolce Agogia are the most cultivated in Umbria. The Spanish cv. Gordal is also present in some areas of the two regions. Leccino and Dolce Agogia are also employed as table olives.

\subsection{Pedologic, climatic and cultivation parameters of the five origin areas.}

The codes and the mean annual values of climatic parameters (concerning 1996) and those of pedologic ones are given in Table I. Regarding cultivation parameters, manuring, in the area of UNI-PG, is done using $2.7 \mathrm{Kg} \mathrm{N}, 0.5 \mathrm{Kg} \mathrm{P}_{2} \mathrm{O}_{5}$ and 2.4 $\mathrm{Kg} \mathrm{K}_{2} \mathrm{O}$ per quintal olives produced every year. In the 
area of ATI-PES, nitrogenous manuring is performed employing $2.0 \mathrm{Kg} \mathrm{N}$ per quintal olives produced every year, while phosphatic manuring is effected using (per $\mathrm{Ha}) 130 \mathrm{Kg} \mathrm{P}_{2} \mathrm{O}_{5}$ every three years, and potassic manuring is performed occasionally. In the area of NRC-PG, manuring is done employing 2.5 $\mathrm{Kg} \mathrm{N}, 0.4 \mathrm{Kg} \mathrm{P}_{2} \mathrm{O}_{5}$ and $2.6 \mathrm{Kg} \mathrm{K}_{2} \mathrm{O}$ per quintal olives produced every year. In the area of UNI-FL, nitrogenous manuring is effected using $150 \mathrm{Kg} \mathrm{N}$ every year and $160 \mathrm{Kg} \cdot \mathrm{P}_{2} \mathrm{O}_{5}$ every two years, while potassic manuring is performed rarely. In the area of
EOI-SPOL, manuring is done employing $2.7 \mathrm{Kg} \mathrm{N}$, $0.3 \mathrm{Kg} \mathrm{P} \mathrm{P}_{2}$ and $2.3 \mathrm{Kg} \mathrm{K}_{2} \mathrm{O}$. In all five cultivation areas, pruning is effected every 1-2 years and irrigation is not performed; $2-3$ harrowings per year and antiparasitic treatments vs. olive fly, black scale and olive leaf spot are done; olive threes having a vase shape with $5 \times 5$ distances are cultivated; in 1996, in every area, the olive production was very low. Thus, in that year, in the five areas, the cultivation techniques used were very similar, while the climatic and pedologic conditions were dissimilar.

Table I

Pedologic and climatic data (means of year 1996) relating to five different olive cultivation areas

\begin{tabular}{|c|c|c|c|c|c|c|}
\hline \multirow{2}{*}{ Codes } & \multirow{2}{*}{ Environmental variables } & \multicolumn{5}{|c|}{ Olive cultivation areas } \\
\hline & & UNIV-PG & NRC-PG & EOI-SPOL & UNIV-FL & ATI-PES \\
\hline & Climatic variables & & & . & & \\
\hline A & Minimum temperature $\left({ }^{\circ} \mathrm{C}\right)$ & 9.6 & 7.6 & 8.3 & 9.0 & 9.6 \\
\hline B & Maximum temperature $\left({ }^{\circ} \mathrm{C}\right)$ & 16.7 & 19.0 & 19.4 & 19.3 & 20.5 \\
\hline C & Sunlight rate (\%) & 53.3 & 46.4 & 48.3 & 43.3 & 41.1 \\
\hline D & Relative humidity of atmosphere (\%) & 65.3 & 63.4 & 64.8 & 67.7 & 66.5 \\
\hline$E$ & Rain days $\left(n .{ }^{0}\right)$ & 122 & 137 & 125 & 179 & 167 \\
\hline $\mathrm{F}$ & Rainfall (mm) & 951.8 & 920.9 & 1141.6 & 1450.6 & 1415.4 \\
\hline G & Velocity of wind (windiness) $(\mathrm{Km} / \mathrm{h})$ & 7.0 & 9.2 & 8.9 & 11.2 & 10.8 \\
\hline \multirow[t]{2}{*}{$\mathrm{H}$} & Elevation & 280 & 252 & 263 & 271 & 277 \\
\hline & Pedologic variables & & & & & \\
\hline 1 & Sand $(\%)$ & 23.8 & 18.2 & 19.7 & 25.3 & 24.5 \\
\hline L & Silt (\%) & 37.4 & 38.6 & 36.2 & 43.2 & 47.7 \\
\hline M & Clay (\%) & 38.8 & 43.2 & 44.1 & 31.5 & 27.8 \\
\hline $\mathrm{N}$ & $\mathrm{pH}$ & 8.1 & 7.6 & 7.8 & 7.5 & 7.2 \\
\hline 0 & Total limestone (\%) & 15.0 & 21.2 & 22.2 & 15.6 & 13.5 \\
\hline$P$ & $\mathrm{C} / \mathrm{N}$ ratio & 6.3 & 6.7 & 7.2 & 7.7 & 7.5 \\
\hline$Q$ & Organic matter (\%) & 0.8 & 1.1 & 1.8 & 1.9 & 1.4 \\
\hline $\mathrm{R}$ & Total nitrogen (\%) & 0.44 & 0.38 & 0.81 & 1.21 & 1.15 \\
\hline$S$ & Assimilable phosphorus (ppm) & 13.0 & 11.2 & 11.8 & 13.3 & 12.1 \\
\hline$T$ & Exchangeable potassium (ppm) & 132 & 145 & 205 & 223 & 281 \\
\hline
\end{tabular}

\subsection{Maturation index, harvesting and processing of the olive samples.}

In the five olive areas, 5 trees (approx. 25 years old) with uniform characteristics were chosen for drupe sampling; a sample of $20 \mathrm{Kg}$ was collected (4 $\mathrm{Kg} /$ tree) in each olive grove zone for each variety. The Moraiolo olive sample was not obtained from ATI-PES area. Harvesting was done by hand at different dates, during the maturation period, whell a same variety reached a similar ripening degree value in the different cultivation areas, as this parameter affects greatly the characteristics of oil. From each of the $20 \mathrm{Kg}$ olive samples, two sub-samples, each weighing $1 \mathrm{Kg}$, were drawn. For each sub-sample, by applying the method proposed by the Estación Experimental de Olivicultura y Elaiotecnia de Mengibar, Jaén, Spain (Uceda et al., 1980; Hermoso et al., 1997), the ripening degree was determined. The pulp/stone ratio and the percentage of oil, moisture and solids were also assessed. The values averaged of olive maturation extent and of other drupe characteristics are given in Table II, together with the dates of olive sampling, and the codes of both samples and fruit features.

After harvesting, the olive samples were rapidly transported to the Istituto Sperimentale per l'Elaiotecnica, 
Pescara, were the drupes were subjected to the above measurements and processed. The fruits were wholesome, not damaged, and fresh.

To process the remaining $18 \mathrm{Kg}$ olive samples to obtain oil samples for analyses, a mini oil-mill (Valpesana S.r.l., S. Casciano Val di Pesa, Italy), equipped with a hammer crusher, a mixer and a basket centrifuge was used. Kneading step lasted only five minutes, and was conducted without warming the paste. The rotary speed of the centrifuging drum was not higher than 2000 $\mathrm{rpm}$. No usage of lukewarm water was done to fluidize the paste during the centrifugation step.

Table II

Data relating to ripening index and other characteristics of three olive varieties harvested at different dates in five different cultivation areas ${ }^{1}$

\begin{tabular}{|c|c|c|c|c|c|c|c|}
\hline & $\begin{array}{c}\text { Cultivation areas and olive } \\
\text { varieties }\end{array}$ & $\begin{array}{l}\text { Harvesting } \\
\text { date }\end{array}$ & $\begin{array}{l}\text { Ripening } \\
\text { index }\end{array}$ & $\begin{array}{l}\text { Pulp/stone } \\
\text { ratio }\end{array}$ & $\begin{array}{l}\text { Oil } \\
(\%)\end{array}$ & $\begin{array}{l}\text { Moisture } \\
(\%)\end{array}$ & $\begin{array}{c}\text { Solids } \\
(\%)\end{array}$ \\
\hline Codes & & & a & b & c & $d$ & e \\
\hline & UNIV-PG & & & & & & \\
\hline PG1Fr & Frantoio & 12.11 .96 & 1.6 & 4.2 & 20.2 & 52.1 & 27.7 \\
\hline PG1Le & Leccino & 12.11 .96 & 4.0 & 4.4 & 16.9 & 58.1 & 25.0 \\
\hline \multirow[t]{2}{*}{ PG1Mo } & Moraiolo & 12.11 .96 & 2.4 & 3.5 & 23.2 & 51.3 & 25.5 \\
\hline & NRC-PG & & & & & & \\
\hline $\mathrm{PG} 2 \mathrm{Fr}$ & Frantoio & 12.11 .96 & 1.6 & 4.3 & 20.7 & 52.7 & 26.6 \\
\hline PG2Le & Leccino & 12.11 .96 & 4.1 & 4.6 & 17.1 & 56.5 & 26.4 \\
\hline \multirow[t]{2}{*}{ PG2Mo } & Moraiolo & 12.11 .96 & 2.4 & 3.7 & 23.2 & 52.4 & 24.4 \\
\hline & EOI-SPOL & & & & & & \\
\hline SPOFr & Frantoio & 16.11 .96 & 1.7 & 4.1 & 21.1 & 53.3 & 25.6 \\
\hline SPOLe & Leccino & 16.11 .96 & 4.1 & 4.5 & 17.5 & 57.3 & 25.2 \\
\hline \multirow[t]{2}{*}{ SPOMo } & Moraiolo & 16.11 .96 & 2.3 & 3.6 & 22.8 & 53.0 & 24.2 \\
\hline & UNI-FL & & & & & & \\
\hline FLFr & Frantoio & 29.11 .96 & 1.7 & 4.4 & 21.4 & 53.0 & 25.6 \\
\hline FLLe & Leccino & 29.11 .96 & 4.0 & 4.4 & 18.0 & 57.7 & 24.3 \\
\hline \multirow[t]{2}{*}{ FLMo } & Moraiolo & 29.11 .96 & 2.3 & 3.6 & 22.5 & 51.9 & 25.6 \\
\hline & ATI-PES & & & & & & \\
\hline PESFr & Frantoio & 25.11 .96 & 1.7 & 4.3 & 20.9 & 51.9 & 28.1 \\
\hline PESLe & Leccino & 25.11 .96 & 3.9 & 4.6 & 17.0 & 56.0 & 27.0 \\
\hline
\end{tabular}

1 Mean values of determinations in duplicate.

\subsection{Oil and olive sample analyses}

For the oil samples, by applying either analytical Community methods (E. C. Regulation N. ${ }^{\circ}$ 2568/91) or non-official ones detailed in previous papers (Ranalli and Angerosa, 1996; Ranalli and Serraiocco, 1996 a,b; Ranalli and De Mattia, 1997; Ranalli et al., 1997), the following determinations were performed:

- high-resolution gas-chromatographic (HRGC) analysis of the phenol fraction by using a 25 $\mathrm{m} \times 0.32 \mathrm{~mm}$ i.d. capillary column coated with $0.1 \mu \mathrm{m}$ of SE-54 (Lab Service Analitica Ltd., Anzola Emilia, Bo, Italy), after extraction with methyl alcohol. The resulting methanolic extract was concentrated to dryness by rotary evaporator, and the residue was subsequently recovered with $10 \mathrm{ml}$ acetonitrile. This solution, after three washings with hexane, was evaporated in vacuum at a temperature below $35^{\circ} \mathrm{C}$. The residue was dissolved into acetone, and 150 $\mu \mathrm{l}$ of bis(trimethyl) trifluoroacetamide were added to $1 \mathrm{ml}$ of this solution. After $1 \mathrm{~h}$, the injection into the gas chromatograph was carried out. The internal standard was resorcinol (> 99\% pure). Free tyrosol and hydroxytyrosol and tyrosol- and hydroxytyrosol-aglycones (dialdehydic forms of elenolic acid linked to tyrosol or hydroxytyrosol) have been identified in the HRGC chromatogram of phenolic fraction (Angerosa et al., 1995); 
- colorimetric determination of total phenols as well as of $o$-diphenols, developing the colour with the Folin Ciocalteus's reagent in the first case and with the Arnow's reagent in the second case and taking the absorbance values at 725 and $450 \mathrm{~nm}$, respectively;

- high-performance liquid chromatographic (HPLC) analysis of tocopherols with a directphase column using a hexane-propan-2-ol $(98.5: 1.5, \mathrm{v} / \mathrm{v})$ eluent and a UV detector at $292 \mathrm{~nm}$ wavelength. This fraction included essentially $\alpha$-tocopherol, while $\beta-, \gamma-$, and $\delta$-tocopherol were present in minute amounts;

- HRGC analysis of headspace volatile aromatic fraction, by using a $25 \mathrm{~m} \times 0.32 \mathrm{~mm}$ i.d. capillary column coated with $0.20 \mu \mathrm{m}$ of carbowax $20 \mathrm{M}$ (Nordion Ltd., Helsinki, Finland) after its extraction by stripping at $37^{\circ} \mathrm{C}$ in a nitrogen stream and entrapping by activated charcoal. The volatiles were then eluted with diethyl ether. The internal standard was nonan-1-ol (>99\% pure). The chromatograms (aromagrams) of this fraction showed many peaks but, as yet, only 21 components have been identified, such as: n-octane, ethyl acetate, 2-methylbutyraldehyde, 3-methyl-butyraldehyde, ethanol, 3-pentanone, 1-penten-3-one, hexanal, isobutyl alcohol, trans-2-pentenal, 1-penten-3-ol, isoamyl alcohol, trans-2-hexenal, n-amyl alcohol, 2-penten-1-ol, 1-hexanal, cis-3-hexen-1-ol, trans-2-hexenol, acetic acid, 1-octanol, 2-butanone;

- HRGC analysis of fatty acids using a $25 \mathrm{~m}$ long $0.35 \mathrm{~mm}$ i.d. capillary column, with a polyglycol type stationary phase. These components were represented by miristic acid $\left(C_{14: 0}\right)$, palmitic acid $\left(C_{16: 0}\right)$, palmitoleic acid $\left(\mathrm{C}_{16: 1}\right)$, heptadecanoic acid $\left(\mathrm{C}_{17: 0}\right)$, heptadecenoic acid $\left(\mathrm{C}_{17: 1}\right)$, stearic acid $\left(C_{18: 0}\right)$, oleic acid $\left(C_{18: 1}\right)$, linoleic acid $\left(C_{18: 3}\right)$, arachidonic acid $\left(\mathrm{C}_{20: 0}\right)$, eicosenoic acid $\left(\mathrm{C}_{20: 1}\right)$, behenic acid $\left(\mathrm{C}_{22: 0}\right)$, lignoceric acid $\left(\mathrm{C}_{24: 0}\right)$;

- HRGC analysis of sterols and triterpene dialcohols, using a $25 \mathrm{~m}$ long $0.30 \mathrm{~mm}$ i.d. glass capillary column, internally coated with SE-52 liquid (0.20 $\mu \mathrm{m}$ uniform thickness). The oil sample was first saponified with an ethanolic $\mathrm{KOH}$ solution, the unsaponifiable matter extracted with diethyl ether, and the components separated on a basic silica-gel TLC plate using a benzene/acetone $(95: 5, \mathrm{v} / \mathrm{v})$ mixture as the eluent. The recovered sterols and dialcohols were transformed into trimethylsilyl (TMS) ethers for analysis. Under UV light, a mildly basic alcoholic 2.7-dichlorofluoroscein solution was used to reveal the component bands for analysis. A pyridinehexamethyl-disilazane-trimethyl- chlorosilane (9:3:1, v/v/v) mixture was used as a silanizing reagent. Internal standard was $\alpha$-cholestanol $\left(0.2 \mathrm{wt} \%\right.$ in $\left.\mathrm{CHCl}_{3}\right)$. This fraction included cholesterol (traces), brassicasterol, 24methylene-cholesterol campesterol, campestanol, stigmasterol, $\Delta^{7}$-campesterol, $\Delta^{5}$-23-stigmastadienol, cholerosterol, $\beta$-sitosterol, sitostanol, $\Delta^{5}$-avenasterol, $\Delta^{5}$-24-stigmastadienol, $\Delta^{7}$-stigmastenol, $\Delta^{7}$ avenasterol. The triterpene dialcohols were represented by erythrodiol and uvaol;

- HRGC analysis of aliphatic and triterpene alcohol fraction. The analytical procedure was similar to that for sterols except that alcohol bands instead of sterols are recovered by the TLC step. Internal standard was arachidilic alcohol. From the data obtained, the alcoholic index was evaluated (Ranalli and De Mattia, 1997). The aliphatic alcohol identified were 1-docosanol $\left(\mathrm{C}_{22}\right)$, 1-tetracosanol $\left(\mathrm{C}_{24}\right)$, 1-hexacosanol $\left(\mathrm{C}_{26}\right)$, and 1-octacosanol $\left(\mathrm{C}_{28}\right)$. The triterpene alcohols identified included $\beta$-amyrin, butyrospermol, cycloartenol, and 24-methylenecycloartanol;

- determination of oxidative stability (induction time of the peroxidation reactions) using a "Rancimat» Model 679 apparatus (Metrohm Co., Basel, Switzerland), which automatically applied the accelerated Swift's test $\left(120^{\circ} \mathrm{C}\right.$; air flow rate $20 \mathrm{l} / \mathrm{h}$ );

- HRGC analysis of waxes using a $\mathrm{SPB}^{\mathrm{th}}-5$ capillary column $(30 \mathrm{~m}, 0.32 \mathrm{~mm}$ i.d., 0.25 $\mu \mathrm{m}$ film tickness, from Supelco Inc., Bellofonte, PA, USA) after their separation with a 70 to 230 mesh hydrated silica gel column and $n$-hexane/diethyl ether $(99: 1, \mathrm{v} / \mathrm{v})$ eluant. The first eluted fraction (approx. $140 \mathrm{ml}$ ), with a polarity lower than the triglycerides, was evaporated to dryness, then recovered with $n$-heptane and finally analyzed. Internal standard was lauryl arachidate. This fraction was represented by waxes $\mathrm{C}_{34}$, waxes $\mathrm{C}_{36}$, waxes $\mathrm{C}_{38}$, waxes $\mathrm{C}_{40}$, waxes $\mathrm{C}_{42}$, waxes $\mathrm{C}_{44}$, and waxes $\mathrm{C}_{46}$; the $\mathrm{C}_{40}+\mathrm{C}_{42}+\mathrm{C}_{44}+\mathrm{C}_{46}$ waxe sum is considered by the E.C. Regulation N. ${ }^{\circ} 2568 / 91$ (E.C., 1991) as a genuineness parameter.

The other analytical observations performed were: spectrophotometric determination of chlorophylls and pheophytins according to Wolff (1968), spectrophotometric determination of chlorophyllic and carotenoid colour indices according to Papaseit Totosaus (1986), determination of color ratio $\left(A_{446} / A_{668}\right)$ directly on oil; determination of brightness $(h \%)$, chroma $(\sigma \%)$ and hue $(\lambda d)$, through 
transmittance measurements (C.I.E method), and calculation of integral color index $(=\sigma \% \log 100 / \mathrm{h} \%)$, and determination of acidity, peroxide index, carbonyl index, UV spectrophotometric indices, and turbidity.

The overall quality index $\left(\mathrm{OQI}_{1}\right)$ was evaluated by the algorithm developed by Olive Oil Council (C.O.I., 1990), based on the acid values, peroxide index and $\mathrm{K}_{270}$ (UV specific extinction at $270 \mathrm{~nm}$ wavelength), as well as the sensory score; the other overall quality index $\left(\mathrm{OQ}_{2}\right)$ involved also the oil polyphenol content (Solinas et al., 1992).

To perform the quantitative descriptive sensory analyses, the COI test included in the E.C. Regulation N. $.^{\circ} 2568 / 91$ (E.C., 1991) was applied, by using a standard profile sheet. This is at present being modified by the $\mathrm{COI}$. The score for each attribute was obtained by using a scale from 1 to 5 and was the result of the whole gustatory - olfactory - tactile perception. A fully trained analytical taste panel made up of 12 assessors, recognized by the $\mathrm{COl}$, and a sensory laboratory were used. The panelists had more than 8 years of experience in evaluating all types of olive oil (extravirgin, virgin, lampant, etc.). Oil samples were heated at $30^{\circ} \mathrm{C}$ by a thermostat before analyses and were presented fully randomised to the tasters. The magnitude of several sensory attributes, such as olive fruity (ripe or green), apple, other ripe fruits, bitter, pungent, sweet, other allowable, sour/winey/vinegary/acid, rough, metallic, mustiness/ humidity, muddy sediment, fusty, rancid, and other unallowable attributes was assessed. Next, an overall evaluation of the magnitudes of positive and negative (off-flavors) attributes was made and, by means of a grading scale, the sensory score obtained. A structured scale ranging from 1 to 9 was adopted.

All oil sample determinations (as for drupe samples) were run in duplicate and the figures averaged.

The percentage of olive paste moisture was determined by oven method keeping at $105^{\circ} \mathrm{C}$ a 50 $\mathrm{g}$ sample until constant weight. The residue was utilized for determination of the oil percentage, which was carried out by using Soxhlet apparatus and petroleum ether (b.p. $40-70^{\circ}$ ) as the solvent. The paste solid percentage was evaluated by the formula: 100 -(oil\% + moisture $\%$ ); the pulp/stone ratio of drupes was determined by using a laboratory blender for their depitting and washing the obtained stones with petroleum ether (b.p. 40-70 ${ }^{\circ}$ ).

\subsection{Statistics}

To process the data, after their normalization, multivariate statistiscs were applied, such as Principal Component Analysis (PCA) and Partial Least Squares regression (PLS2). The cross-validation procedure was used to determine the maximum number of significant dimensions to avoid data over-fitting. The multivariate evaluation of the effects of the experimental factors were made. The statistical package Unscrambler II Version 5. 52 /CAMO A/S, Trondheim, Norway) was used. For Hierarchical Cluster Analysis (HCA) the statistical Genstat software was utilized.

\section{RESULTS AND DISCUSSION}

The PCA of the agronomic data set (concerning climatic and pedologic variables) $(5 \times 18$ matrix $)$ showed that the two first principal components (PCs) explained approx. $70 \%$ of the total variance. The score-plot (Figure 1) by the dimensions 1 and 2 showed that the three Umbrian olive areas were well-differentiated, while the two Tuscany areas, which were positioned along the second component, were not very discriminated. Figure 2 shows the loadings for the dimensions 1 and 2, that point to which variables contributed to the discrimination of the olive areas.

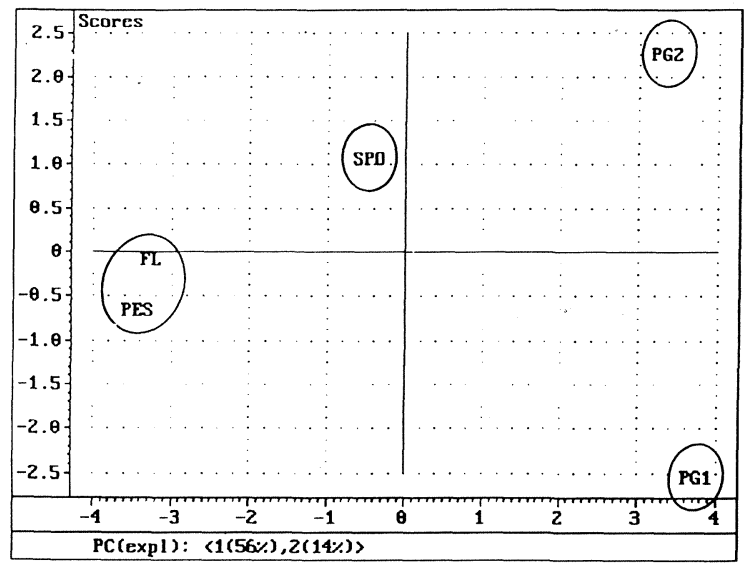

Figure 1

Score-plot of cultivation areas by the dimensions 1 and 2 from PCA of climatic and pedologic variables

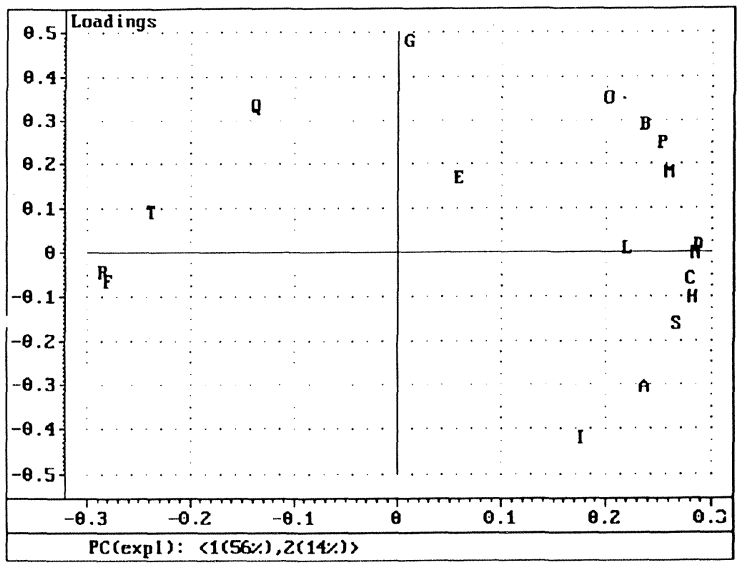

Figure 2

PCA loadings of climatic and pedologic variables for dimensions 1 and 2 
The PCA of the data set of characteristics of drupes ( $14 \times 5$ matrix) showed that the first two eigenvectors accounted for approx. $90 \%$ of the total variance. The PCA scores of the objects on the 1 and 2 dimensions (Figure 3 ) indicated that the olive varieties, independently of cultivation areas, were clearly discriminated along the two first PCs (Frantoio and Moraiolo on the negative half and Leccino on the positive side). This was showed also by the Hierarchical Cluster Analysis. In fact, the dendrogram (not shown) displayed three great blocks each constituted by a same variety, with a similarity percentage within each block more than $65 \%$. Each block was divided into sub-blocks depending on the cultivation areas, characterised by similarity percentages up to $95 \%$.

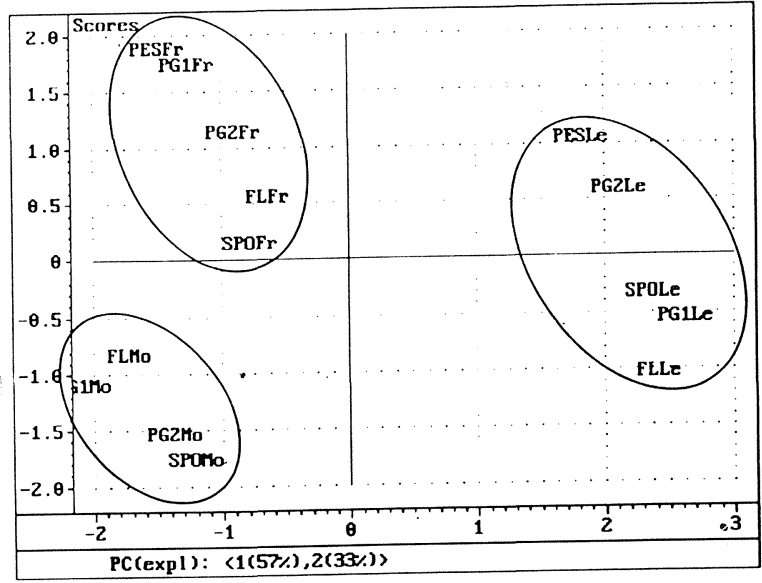

Figure 3

Score-plot of cultivation area/variety combinations by the dimensions 1 and 2 from PCA of drupe variety features

Table III

The loading-plot (not shown) from the first two eigenvectors indicated that the ripening index, oil \%, and moisture \% of drupes (Table II) were important in describing the first component, while the pulp/stone ratio and solids \% variables were important in describing the second component. By comparing the score-plot with the loading-plot it was noticed that the ripening index, pulp/stone ratio and moisture \% variables were mainly responsible for the discrimination of the Leccino variety, while the Frantoio variety was mainly differentiated by the solids \% variable, and the Moraiolo variety by the oil $\%$ variable.

The PCA of the original analytical oil data led to identify three valid PCs which accounted for approx. $54 \%$ of total variance. The 2D and 3D score-plots (not shown) by the first three PCs showed that both origin area and olive variety were not welldifferentiated.

By means of loadings, a screening of the original analytical oil variables was made, and those selected, accounting for a higher variance percentage, are reported in Table III, together with their values (averaged for variety), standard deviation, and codes. The PCA was applied to the reduced $14 \times 20$ matrix and the model improved as the first three significant components explained approx. $80 \%$ of total variance.

Codes of the 20 selected analytical oil variables and their mean values \pm SD for each olive variety

\begin{tabular}{|c|c|c|c|c|}
\hline Codes & Selected analytical oil variables & Leccino & Frantoio & Moraiolo \\
\hline 1 & Acidity $(\%$, oleic acid $)$ & $0.28 \pm 0.04$ & $0.36 \pm 0.05$ & $0.43 \pm 0.05$ \\
\hline 2 & Total phenols (mg/Kg, caffeic acid) & $323 \pm 187$ & $304 \pm 139$ & $392 \pm 107$ \\
\hline 3 & O-diphenols (mg/Kg, caffeic acid) & $215 \pm 123$ & $202 \pm 92$ & $245 \pm 64$ \\
\hline 4 & Hydroxytyrosol-aglicones (mg/Kg, resorcinol) & $140 \pm 89$ & $83 \pm 55$ & $172 \pm 39$ \\
\hline 5 & $\mathrm{~K}_{232}$ & $1.34 \pm 0.10$ & $1.36 \pm 0.17$ & $1.47 \pm 0.07$ \\
\hline 6 & Wolff's ratio $(\mathrm{R})$ & $15.4 \pm 3.4$ & $12.4 \pm 1.5$ & $13.5 \pm 1.3$ \\
\hline 7 & Sensory score & $7.0 \pm 0.2$ & $6.9 \pm 0.1$ & $7.0 \pm 0.2$ \\
\hline 8 & OQI1 & $7.8 \pm 0.3$ & $7.4 \pm 0.4$ & $7.3 \pm 0.2$ \\
\hline 9 & OQ12 & $39.6 \pm 2.2$ & $38.0 \pm 1.7$ & $39.2 \pm 1.7$ \\
\hline 10 & $\alpha$-Tocopherol (mg/Kg) & $113.3 \pm 16.4$ & $74.7 \pm 15.8$ & $84.8 \pm 12.8$ \\
\hline 11 & Oleic acid (\%) & $79.8 \pm 0.5$ & $81.3 \pm 1.7$ & $80.6 \pm 0.5$ \\
\hline 12 & Linoleic acid $(\%)$ & $4.1 \pm 0.3$ & $5.0 \pm 0.9$ & $5.3 \pm 0.4$ \\
\hline 13 & Unsaturated fatty acids/Polyunsaturated fatty acids & $18.8 \pm 1.2$ & $16.1 \pm 2.7$ & $14.9 \pm 1.0$ \\
\hline 14 & Oleic acid/Linoleic acid & $19.8 \pm 1.6$ & $16.7 \pm 3.5$ & $15.3 \pm 1.0$ \\
\hline 15 & Waxes $\left(\mathrm{C}_{40}+\mathrm{C}_{42}+\mathrm{C}_{44}+\mathrm{C}_{46}\right)(\mathrm{mg} / \mathrm{Kg})$ & $31.6 \pm 7.1$ & $54.0 \pm 15.2$ & $89.2 \pm 35.1$ \\
\hline 16 & Alcoholic index & $0.19 \pm 0.07$ & $0.23 \pm 0.14$ & $0.56 \pm 0.26$ \\
\hline 17 & Total sterols $(\mathrm{mg} / 100 \mathrm{~g})$ & $125.5 \pm 12.4$ & $135.6 \pm 10.5$ & $110.8 \pm 5.1$ \\
\hline 18 & Triterpenic dialcohols $(\mathrm{mg} / 100 \mathrm{~g})$ & $1.3 \pm 0.3$ & $1.9 \pm 0.7$ & $2.9 \pm 0.8$ \\
\hline 19 & Pleasant volatiles (nonan-1-ol, mg/Kg) & $457 \pm 182$ & $505 \pm 219$ & $293 \pm 34$ \\
\hline 20 & Fruitiness & $2.2 \pm 0.2$ & $2.2 \pm 0.2$ & $2.2 \pm 0.1$ \\
\hline
\end{tabular}


To explore the relationships between climatic and pedologic parameters and the $\mathrm{N} .{ }^{\circ} 20$ analytical oil variables selected by PCA, the Partial Least Squares in latent variables (PLS2) was used. Three PCs was found to be statistically significant, which accounted for more than $70 \%$ of total $Y$-variance. The $X$ - and Y-loadings for PC 1 vs. PC2 (Figure 4) indicated the following: (i) waxes (C40+C42+C44 + C46) could negatively correlate with organic matter of soil; (ii) fruitiness, oleic acid, linoleic acid, sensory score, OQ11, OQI2, and total sterols could negatively correlate with limestone percentage of soil; (iii) $\alpha$-tocopherol, pleasant volatiles, oleic acid/linoleic acid ratio and unsaturated/polyunsaturated fatty acid ratio could indirectly negatively be influenced by windiness, while this variable could positively influence o-diphenols, hydroxytyrosol aglycones and total phenols (as it reduces the humidity of soil), in accord with Servili et al. (1990) and Pannelli et al. (1993); (IV) fruitiness could also negatively be affected by maximum air temperature and $\mathrm{C} / \mathrm{N}$ ratio of soil. There were other correlations the above loadings enabled to hypothesize, but it is wise to wait for further data we will obtain in the next years before drafting conclusions. The relationships between the trend of climatic variables (especially rainfall and temperature), during growth and ripening of drupes, and analytical oil variables, we will also explore.

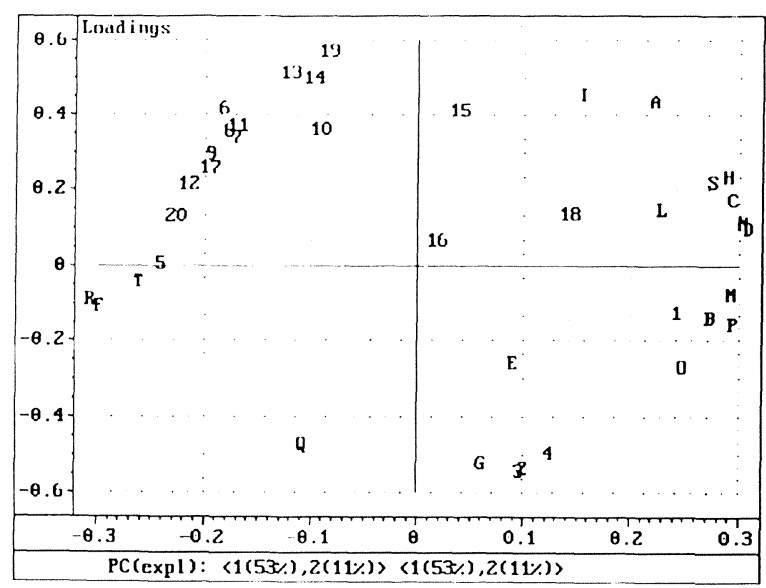

Figure 4

PLS2 loadings of selected analytical oil variables $(Y)$ and climatic and pedologic variables $(X)$ for latent components 1 and 2

The estimation of effects of the 14 objects (cultivation area/olive variety combinations) on the $\mathrm{N} .{ }^{\circ} 20$ analytical oil variables was made. There was a fractional factorial design as the PESMo olive sample was missing. To validate the model, leverage correction was used, as there are not replicates. The main effects confounded with two-way interaction effects were estimated. By running PLS 1, the effects for each $Y$-variable were estimated. Factorial designs give only one PLS component per Y-variable (because all variables vary equally). This means that the systematic variation of the data set is completely described by one PC. For each Y-variable a normal distribution plot was obtained, showing the significant and the non-significant effects, the latter being those that were located along the straight line through $(0 ; 50)$. To interpret the results, the $\beta$-coefficients were also used. The values of the estimated effects are two times the $\beta$-values. Subsequently, a diagnosis of the model for each $Y$-variable was made. A new model, including only the significant effects, was made. The plot of residuals showed that they were practically all on a straight line through (0:50), i. e., were normally distributed and thus the fit was adequate. Finally, the plot of residual vs. predicted values of the reduced model showed that the residuals were scattered randomly around the zero line, i. e., there were no systematic patterns in the residuals. This means that there was no unexplained systematic variation in the response, due to systematic variation in the insignificant design variables. Again the model seemed to be satisfactory. Figures 5, 6, and 7 show, as an example, some of the plots and the $\beta$-coefficients only for the total phenol $Y$-variable. The significant effects for the $N .^{\circ} 20$ analytical Y-variables have been summarized in a Table (not shown). There were, as expected, many significant effects due to the environment/olive variety combinations. However, both cultivation area and olive variety were not sufficiently discriminated, i. e., there was not a clearly overall predominant effect exerted by one of the two factors. However, the elevated standard deviation value recorded for some variables (e. g. total phenols, o-diphenols, hydroxytyrosol-aglycones, pleasant volatiles), by averaging the analytical figures for variety (Table III), suggested that they were preponderantly affected by the cultivation area factor.

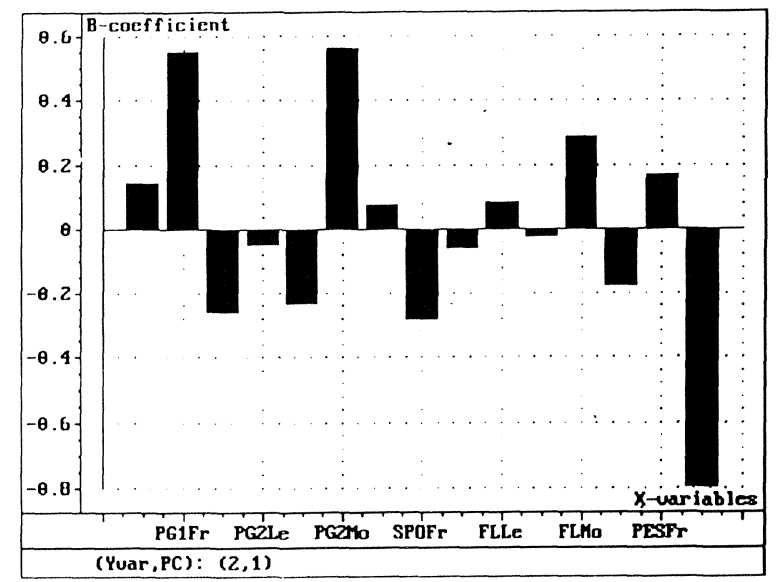

Figure 5

$\beta$-coefficients of cultivation area/olive variety combinations for oil phenol content variable of reduced model 


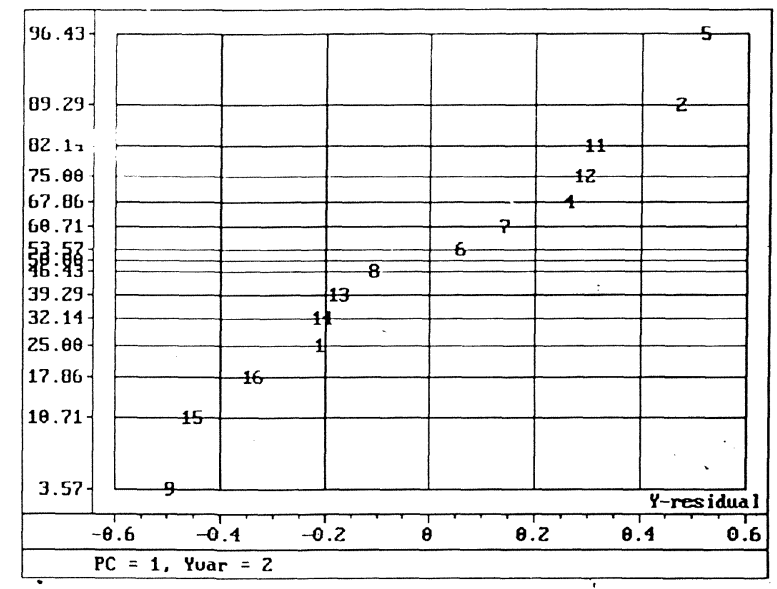

Figure 6

Normal distribution plot of residuals for oil phenol content variable of reduced model

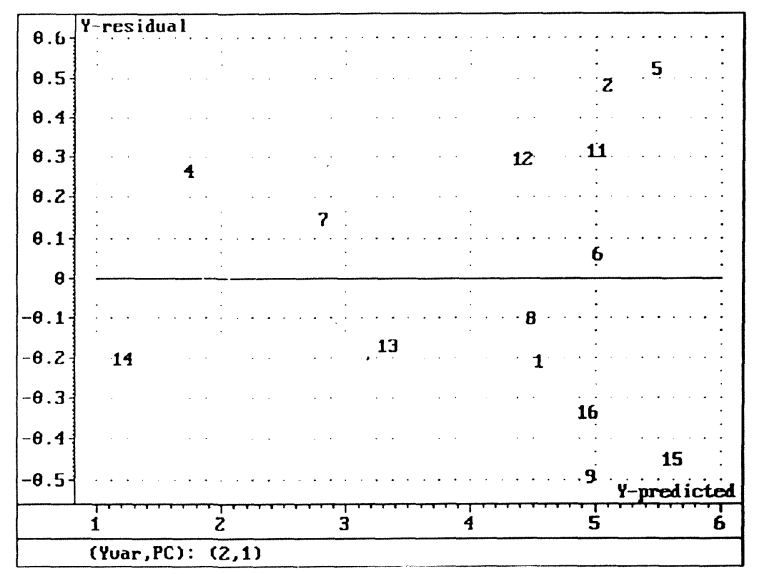

Figure 7

Residual vs. predicted values from reduced model for oil phenol content variable

\section{ACKNOWLEDGMENT}

Prof A. Tombesi took the olive samples from UNI-PG area; Dr. G. Vergari took the olive samples from NRC-PG area; Dr. G. Pannelli took the olive samples from EOI-SPOL area; Prof G. Galligani took the olive samples from ATI-PES area; Prof P. Fiorino took the olive samples from UNI-FL area. We thank the Agriculture Ecology Institute of University of Perugia for providing the meteorological data relating to the area of UNI-PG. Financial support was provided by the Italian Ministry for Agricultural Policies, Rome, Italy. The study was approved by the National Committee of Agricultural Experimentation, Rome, Italy.

\section{REFERENCES}

Alonso, V., Aparicio, R (1993).- «Characterization of European virgin olive oils using fatty acids".-Grasas y Aceites 44, 18-24.

Angerosa, F., D'Alessandro, N., Konstantinou, P., Di Giacinto, L. (1995).— «GC-MS evaluation of phenolic compounds in virgin olive oil».-J. Agric. Food Chem. 43, $1802-1807$.

Angerosa, F., Di Giacinto, L., Basti C., Serraiocco, A. (1996).- - Influence of the environment variable on composition of virgin olive oil».-Riv. Ital. Sostanze Grasse 73, 461-467.

Aparicio, R (1988). - «Characterization of foods by inexact rules: the sexia expert system».-J. Chemometrics 3, 175-192.

Aparicio, R, Albi T., Lanzón, A., Navas, M. A. (1987)."SEXIA: an expert system to oil identification: data base from olive grove zones".- Grasas y Aceites 38, 9-14.

Aparicio. R., Alonso, V. (1994).-«Characterization of virgin olive oils by SEXIA Expert System».-Prog. Lipid Res. 33, 29-38.

Aparicio, R., Alonso, V., Morales, M. T. (1994)._- ¿Detailed and exhaustive study of the authentication of European virgin olive oils by SEXIA expert system».-Grasas y Aceites 45, 247-252.

Aparicio, R., Ferreiro, L., Cert, A., Lanzón, A. (1990)."Characterization of virgin olive oil».-Grasas y Aceites 41, 23-39.

Aparicio, R., Ferreiro, L., Rodríguez, J. L. (1991)."Characterization of Andalusian virgin olive oils: SEXIA project».-Andalusian Ministry of Agriculture, Sevilla, Spain.

Aparicio, R., Ferreiro, L., Alonso, V. (1994).-Effect of climate on the chemical composition of virgin olive oil».-Anal. Chim. Acta 292, 235-241.

Armanino, C., Leardi R,. Modi G. (1989).- «Chemometric analysis of Tuscany olive oils".-Chemometric and Intelligent Laboratory Systems 3, 343-354.

Balestrieri F., Marini D., Salpietro, S. (1995).-«Multivariate analysis applied to the discrimination of Umbrian extravirgin olive oils".- Riv. Sci. Alimentazione 24, 15-22.

Bianchi G., Giansante, L., Lazzari, M. (1996).— -Analysis for the protection of genuineness and origin of olive oil».-L'Infor. Agrario 72, 45-48.

Bianchi G., Pozzi N. (1994).——Dihydroxyphenylglycol, a major $\mathrm{C}_{6}-\mathrm{C}_{2}$ phenolic in Olea europaea fruits".Phytochemistry 35, 1335-1337.

Cimato, A., Sani G., Mattei M., Osti M. (1990).— «Cultivars and environment as regulating factors in poliphenol and tocopherol contents of the Tuscan oils".Horticulturae 286, 457-462.

C.O.I. (1990).— - Definition of the overall quality index of virgin olive oil: ring test results and its adoption".Olivae 4, 6, 5 .

Deidda, P., Nieddu, G., Spano, D., Bandino, G., Orrù, V., Serraiocco, A., Solinas, M. (1993).— -Olive oil quality in relation to environmental conditions".-Presented at the 2nd International Symposium on "Olive Growing», Jerusalem, Israel, September 6-10.

Derde, M. P., Coomans, D., Massart, D. L. (1984)."SIMCA" (Soft Independent modeling of class analogy). Demonstrated with characterization and classification of Italian olive oil".- J. Assoc. Off. Anal. Chem. 67, 721-727.

Drava, G., Forina, M., Lanteri S. (1994).- «Development of the chemical model of a typical food product: olive 
oil from an Italian region (Basilicata)".-J. Sci. Food Agric. 65, 21-30.

E. C. (1991).- «Commission Regulation E. C. N. ${ }^{0} 2568 / 91$ of 11 July 1991 on the characteristics of olive oil and olive residue oil and on the relevant methods of analysis".-Official J. L 248, 05-09-91.

Ferreiro, L., Aparicio, R (1992).- «Influence of altitude on the chemical composition of virgin olive oil».-Grasas y Aceites 43, 149-155.

Fiorino, P., Nizzi Griffi, F. (1991).- «Maturation index of olives and variations of some components of its oil».-Olivae 35, 25-33.

Forcadell, M. L., Lopez, M. C., Torre, M. C. (1988)."Classification of virgin olive oils from different origin by discriminant analysis».-Riv. Ital. Sostanze Grasse 65, 213-214.

Forina, M., Armanino, C., Lanteri S., Calcagno C., Tiscornia, E. (1983).- - Correlation of chemical olive oil features with the production year through multivariate methods of classification".-Riv. Ital. Sostanze Grasse 60, 607-613.

Forina, M., Tiscornia, E. (1982). — «Pattern methods in the prediction of Italian olive oil origin by their fatty acid content».-Ann. Chim. 72, 143-149.

García, A., Aparicio, R (1993).- «Characterization of european virgin olive oils using fatty acids".- Grasas y Aceites 44, 18-24.

Giglioli, A., Daghetta, A., Sidoli, A. (1993).—«Research on triglyceride content in extravirgin olive oils of different geographic origin».- Riv. Ital. Sostanze Grasse 70, 483-489.

H. Hermoso, M., Ferreira, J., Frías, L., Beltram, M. (1997).«Olive growing», chapter 6, «Maturation».-Pp. 135-153, Scientific Editors, Spain.

Leone, A. M., Liuzzi V., La Notte, E., Santoro, M. (1994).— «Sterols, methylsterols and dimethylsterols of olive and other vegetable oils. Possible role in the characterization of some products".-Riv. Ital. Sostanze Grasse 61, 69-89.

Kiritsakis, A. K., Markakis, P. (1987).-—Olive oil a review».-Advance Food Researche 31, 118-125.

Leardi R., Paganuzzi V. (1987).- -Characterization of the origin of extravirgin olive oils performed through the use of chemometrical methods on the sterolic fraction».-Riv. Ital. Sostanze Grasse 64, 131-136.

Lotti, G., Izzo, R., Riu, R (1992).- - Influence of climate on the fatty acids and sterol composition of olive oil».-Riv. Sci. Alimentazione 11, 115-121.

Montedoro, G. F. (1992).- «The genetic and agronomic factors of olive oil quality».-Uliveto 18, 6-12.

Montedoro, G. F., Garofalo, L. (1984).- «Qualitative characteristics of virgin olive oil. Influence of some variables, such as variety, environment, storage, extraction and conditioning of the final product».-Riv. Ital. Sostanze Grasse 61, 157-168.

Montedoro, G. F., Garofalo, L., Bertuccioli, M., Pannelli, G. (1989).- "Influence of the cultivar and pedoclimatic conditions on the virgin olive oil quality".-Presented at the International Flavor Conference «Flavors and off-flavors», Rethymno, Crete, Greece, July 5-7.

Montedoro, G. F., Servili, M. (1992).- «The quality parameters of olive oil and the agronomic and technological factors that influence them».-Riv. Ital. Sostanze Grasse 69, 563-573.

Montedoro, G. F., Servili, M., Baldioli, M., Magnarini, C., Cossignani, L., Damiani, P. (1993).- «The potential models which define the typicalness of COD extravirgin olive oils».-Ind. Alimentari 32, 618-626.
Montedoro, G. F., Servili, M., Baldioli, M., Selvaggini, R. Perretti, G., Magnarini, C., Cossignani, L., Damiani P. (1995). - «Characterization of some Italian virgin olive oils in relation to origin area».-Riv. Ital. Sostanze Grasse 72, 403-412.

Montedoro, G. F., Servili, M., Pannelli, G. (1993)-—«The agronomic factors of olive oil quality and the interrelationships with the technological extraction process".-Presented at the meeting on the Spanish olive growing, Spoleto, Italy, September 8.

Olias, J.M. (1992).—-Definition of extravirgin olive oils».-Presented at the International Congress «Olive Oil Quality», Florence, Italy, December 1-3.

Osman, M., Metzidakis, I., Gerasopoulas, D., Kiritsakis, A. (1994).- «Qualitative changes in olive oil of fruits collected from trees grown at two altitudes".-Riv. Ital. Sostanze Grasse 71, 187-190.

Pannelli, G., Famiani, F., Servili, M., Montedoro, G. F. (1993).- «Agro-climatic factors and characteristics of the composition of virgin olive oil».-Presented at the 2nd International Symposium on "Olive Growing", Jerusalem, Israel, September 6-10.

Pannelli, G., Montedoro, G. F. (1988).—-Variety, pedoclimatic conditions and ripening degree of olive fruit and qualitative characteristics of oil».-Presented at the Congress on «Maturation, Storage and Processing Aspects of Olive Fruits», Turin, Italy, October 3-4.

Pannelli, G., Servili, M. (1995).- «The agronomic factors of production and quality of olive oil».-Presented at the meeting «The olive growing in Mediterranean countries: techniques and policies in comparison to get ready a developing project», December 6-7, Rome, Italy.

Pannelli, G., Servili, M., Selvaggini, R., Baldioli, M., Montedoro, G.F. (1993).- - Effect of agronomic and seasonal factors on olive (Olea europaea L.) production and on the qualitative characteristics of the oil».-Presented at the 2nd International Symposium on "Olive Growing", Jerusalem, Israel, September 6-10.

Ranalli, A. (1989).- «Aspects of, and problems connected with, the storage and preservation of olive oil».Olivae 6, 11-18.

Ranalli, A., Angerosa, F. (1996)._- Integral centrifuges for olive oil extraction. The qualitative characteristics of products".-J. Am. Oil Chem. Soc. 73, 417-422.

Ranalli, A., De Mattia, G. (1997)._- Characterization of olive oil produced with a new enzyme processing aid".-J. Am. Oil Chem. Soc. 74, 1105-1113.

Ranalli, A., De Mattia, G., Ferrante, M. L. (1997)."Comparative evaluation of the olive oil given by a new processing system».-Int. J. Food Sci. Tech. 32, 289-297.

Ranalli, A., Serraiocco, A. (1996a).- «Quantitative and qualitative effects of a pectolytic enzyme in olive oil production".-Grasas y Aceites 47, 227-236.

Ranalli, A., Serraiocco, A. (1996b).- «Evaluation of characteristics of olive oil produced by innovative or traditional processing technologies".-Riv. Ital. Sostanze Grasse 73, 303-315.

Papaseit Totosaus, G. (1986).- - "The quality of virgin olive oil as a function of color».-Grasas y Aceites 37, 204-206.

Servili, M., Montedoro, G.F., Pannelli, G., Famiani, F. (1990)."Influence of pedoclimatic, technological and genetic factors on the quality of virgin olive oil».-Presented at the meeting "Qualitative Problems of Olive Oil», Sassari, Italy, November 6. 
Servili, M., Pannelli, G., Selvaggini, R., Baldioli, M., Montedoro, G. F. (1993). - «Virgin olive oil composition in relation to agronomic factors".-Presented at the meeting «Rules, Techniques, and Quality in Olive Growing", Potenza, Italy, December 15-17.

Solinas, M., Angerosa, F. (1989).— «New quality indices of virgin olive oil».-Presented at the International Congress "Chevreul» for the study of fatty substances, Angers, France, June 6-9.

Solinas, M., Bandino, G., Orrù, V. (1990).— «Approach methodology to the study of the interrelationships between olive agronomic parameters and quality of the Sardinian olive oils".-Presented at the meeting "Qualitative problems of olive oils", Sassari, Italy, November 6.

Solinas, M., Bandino, G., Orrù, V. (1992).—«Relationships between agronomic parameters and quality of olive oil»._L'Infor. Agrario, 14, 65-68.
Tous, J., Romero, A. (1993).-"Cultivar and location effects on olive oil quality in Catalonia".--Presented at the 2nd International Symposium on "Olive Growing", Jerusalem, Israel, September 6-10.

Tsimidou, M., Karakostas, K. X. (1993).-«Geographical classification of Greek virgin olive oil by non-parametric multivariate evaluation of fatty acid composition».-J. Sci. Food Agric. 62, 253-257.

Uceda, M., Ferreira, J., Frias, L. (1980).- «Contribution to the study of olive oil'.--Patners' meeting, Institute of Lipids and Lipid derivatives, Sevilla, Spain.

Wolff, J. P. (1968)._«Lipid analysis manual».-Azoulay Editor, Paris, France.

Recibido: Enero 1998 Aceptado: Diciembre 1998 